
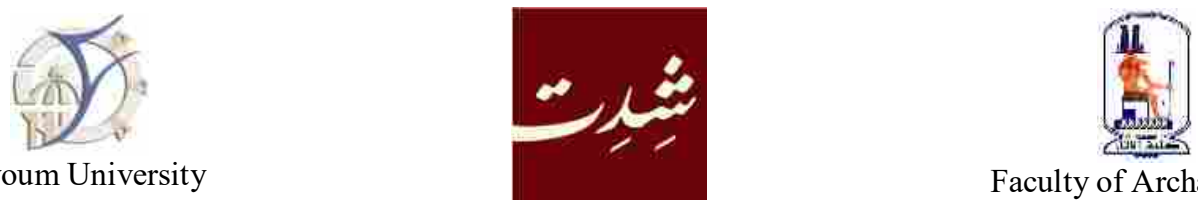

Fayoum University

Faculty of Archaeology

\title{
THE MEDRESE AND IMARET OF HAYREDDIN BARBAROSSA ON THE ISLAND OF LESBOS/MIDILLI: \\ A LITTLE-KNOWN ASPECT OF THE CULTURAL HISTORY OF SAPPHO'S ISLAND UNDER THE OTTOMANS (1462-1912)*
}

\author{
Machiel KIEL \\ Emeritus Professor of Islamic Architecture and Civilization \\ Former Director of the Netherlands Institute in Turkey (NIT) \\ Honorary Member of the Turkish Historical Association \& Senior Research Fellow of the NIT \\ E.mail: machiel.kiel@googlemail.com
}

\begin{abstract}
الملخص

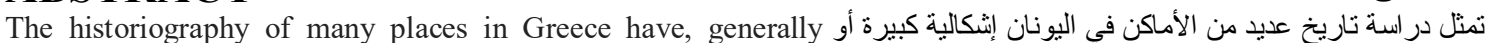

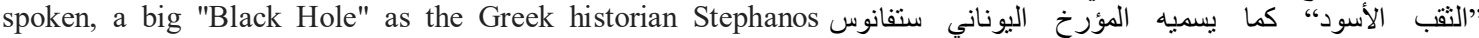

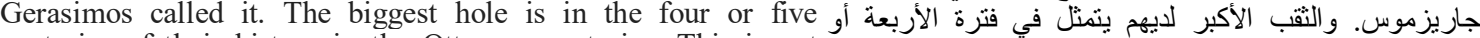

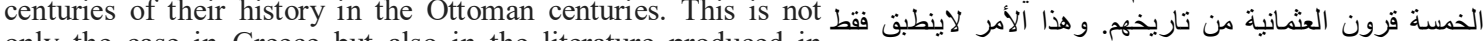

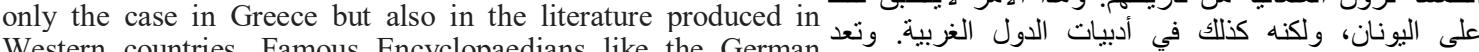

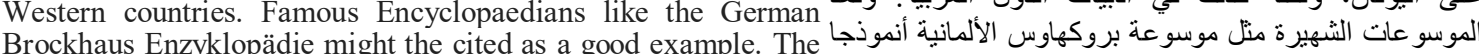

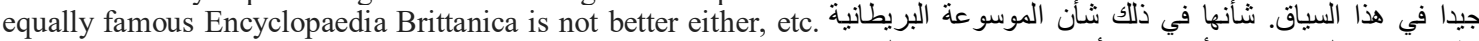

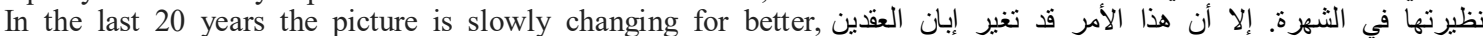

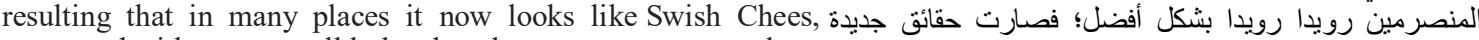

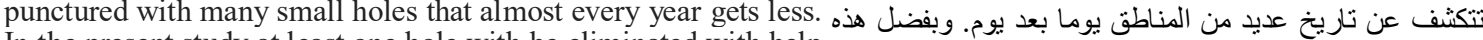

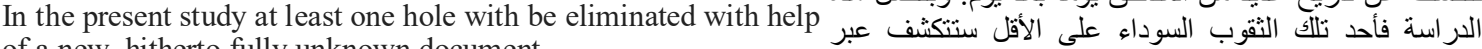
of a new, hitherto fully unknown document.

It begins with a two page survey of the main outlines of the در اسة وثيقة جديدة غير منثورة.

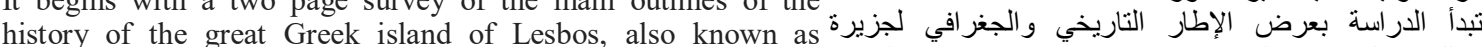

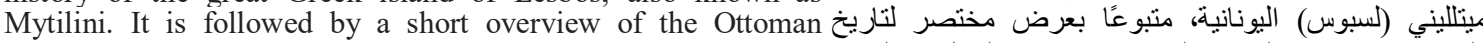
administrative records about the island.

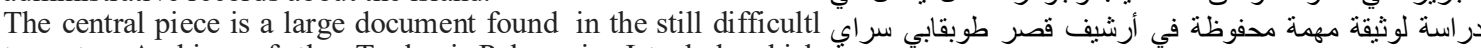

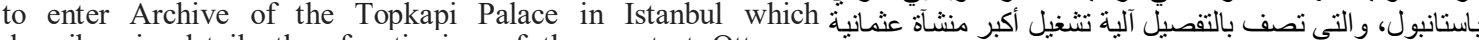

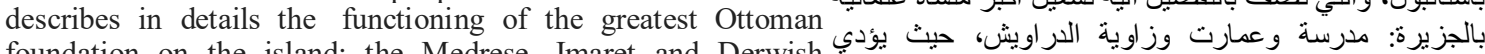

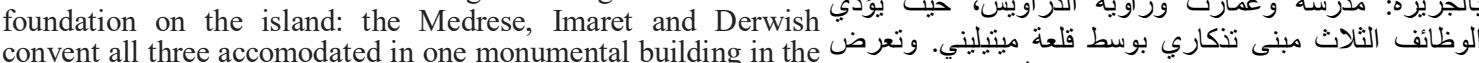

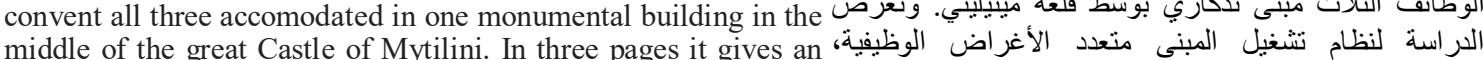

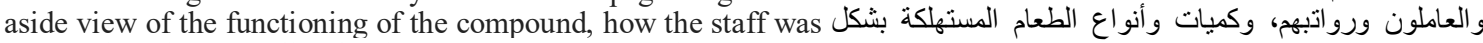

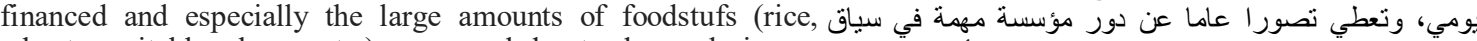

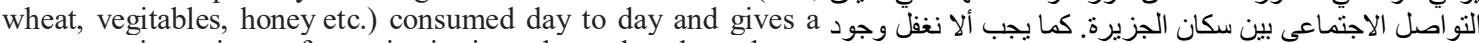

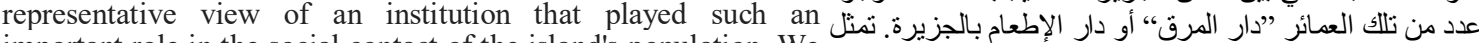

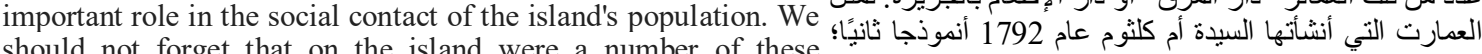

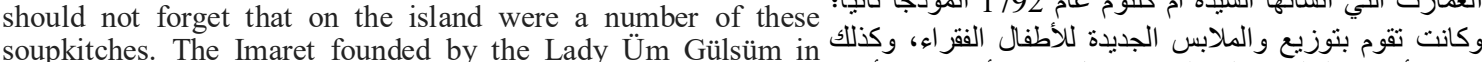
1792 distributing food and new dresses for poor children and الوزيع أطباق الحلوى على الجميع خلال عيد الأضحى والأعياد distribution of sweet dishes to everybody during the Bayrams and

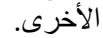
other festivities.(B.O.A. "Vakfiyeler, Dosya 1, Gömlek 29.) It وتجدر الإشارة كذلك أنه كانت ثمة قاعدة تتمثل في عدم منع دخول

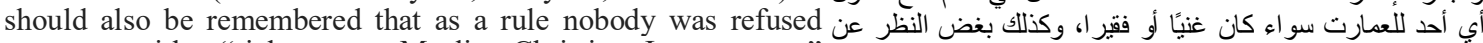
entrance, neither "rich or poor, Muslim, Christian, Jew or pagan" ديأنته؛ و هو ما سجله الرحالة الغربيون مبدون عظيم دهشتهم. as the western traveller found to their great astonishment.
\end{abstract}

\section{KEYWORDS}

Medrese - Imaret - Hayreddin Barbarossa - Ottoman

- Lesbos - Mytilene - Balkan

*- This article was dedicated to Professor Halil İnalcık; it was previously submitted to a volume of studies dedicated to him but it is never appeared. 


\section{INTRODUCTION}

In the multi-millennium history of the Greek island of Lesbos/Mytilene (Midilli to the Ottomans) the time it was part of the Ottoman Empire was but a transitory episode, although lasting 450 years. The population of the island, which in the early 17 th century reached over 50.000 souls, remained for three quarters or more Greek Christian. Yet the fact that the Muslims of the island supported among them a Sufi order as high-principled and sophisticated as the Mevleviye Order tells us a lot of the character of that community. ${ }^{1}$

Knowledge of Midilli's political and economic history, the changes in its settlement pattern, and the cultural development of its Muslim and Christian communities will not change our understanding of the Otto-man Empire it will only deepen it, reflecting as it does the situation on the periphery, where various influences blend. Moreover, it is in the outlying provinces, rather than in the core of an empire, that we can see the strength of its civilization. We therefore thought it suitable to devote a few pages to the little-researched Ottoman period (1462-1912) of Sappho's island, and dedicate them to Halil İnalc1k, who did so much to improve our knowledge and understanding of the grand old empire, in general and in detail.

Before we (Dimitris Karidis and Machiel Kiel) ${ }^{2}$ started the work on the economic changes and development of the island's population and the works of Ottoman architecture left behind the Ottoman Period was very little was known. In the article "Midilli" in the authoritative Ency-clopedia of Islam (Leiden, Brill publishers) the period between the siege of the town of Mytilini by a Christian fleet of 200 ships under command of Count Ravenstein in 1501 until the Greek Struggle for Independence (1821-1830) not a single word can be found (!) With the book "Mytilinis Astygraphia kai Lesvos Chronografia" Athens 2000, the two above mentioned authors filled a void of more than three centuries in broad outlines, enough still needs to be done to make the picture complete.

The great island of Lesbos/ Mytilene (75 km long from east to west and 50 from north to south) is situated opposite of the coast of north-western Anatolia well within sight of the mainland. From the old Anatolian port of Ayazmend (now: Altınova) to Mytilene town is only an hour and a half sailing, from Bahram Kale to the second historical town of the island, Molyvos/Molova, even less (the distance is but $8 \mathrm{~km}$ ). In fact, the settlement pattern and economy of the island was throughout history, oriented towards Anatolia, "turning its back" to the Greek mainland far away across the Aegean, the eastern part of the island being the most densely inhabited the western part was almost devoid of human population.

In the $12^{\text {th }}$ century BC the island was colonised by the Greeks. It reached the peak of power

\footnotetext{
${ }^{1}$ - The Mevlevihâne of Midilli is mentioned in the survey of the geographical spread of the order, given by Albülbaki Gölpınarlı in his classic work "Mevlanâ'dan sonra Mevlevilik" Istanbul 1953 (and further editions), pp. 334-335. More on the history of the Midilli convent is given in the work of the historian of the order, Sakıb Mustafa Dede, "Sefine-i nefise-i Mevleviyân," written before 1735 and printed in Cairo 1283 $(1866 / 67)$. A number of Ottoman documents, attesting the existence of the order on the island, are given by M. Kiel, "Quellen zur Geschichte des Mevlevi-hâne von Midilli/Lesbos" in print, where documents from 1725, 1776 and 1827 and 1840 are given. For details on many other Mevlevi-hânes, their architecture and their history, see: Osmanlı Araştırmalart-Journal of Ottoman Studies, XIV, Istanbul, 1994, an issue especially devoted to this topic.

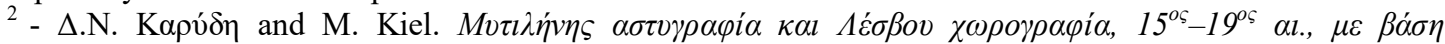

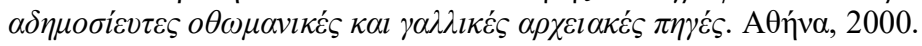

- 163 - $\mid$ The Medrese and Imaret of Hayreddin Barbarossa on the Island of Lesbos/Midilli 
and prosperity in the $6^{\text {th }}$ century $\mathrm{BC}$ under the local tyrant Pittakos. ${ }^{3}$ The vast circumference of the antique town walls of Mytilene and Methymna (Molova) still indicate the dense population the island must have had in that time. ${ }^{4}$ After the downfall of the Ancient World, the general decline and disappearance of population, the depredations of the Arab fleets, later followed by those of the Turkish Emir Çaka, led, as everywhere in the Aegean, to large-scale depopulation. ${ }^{5}$

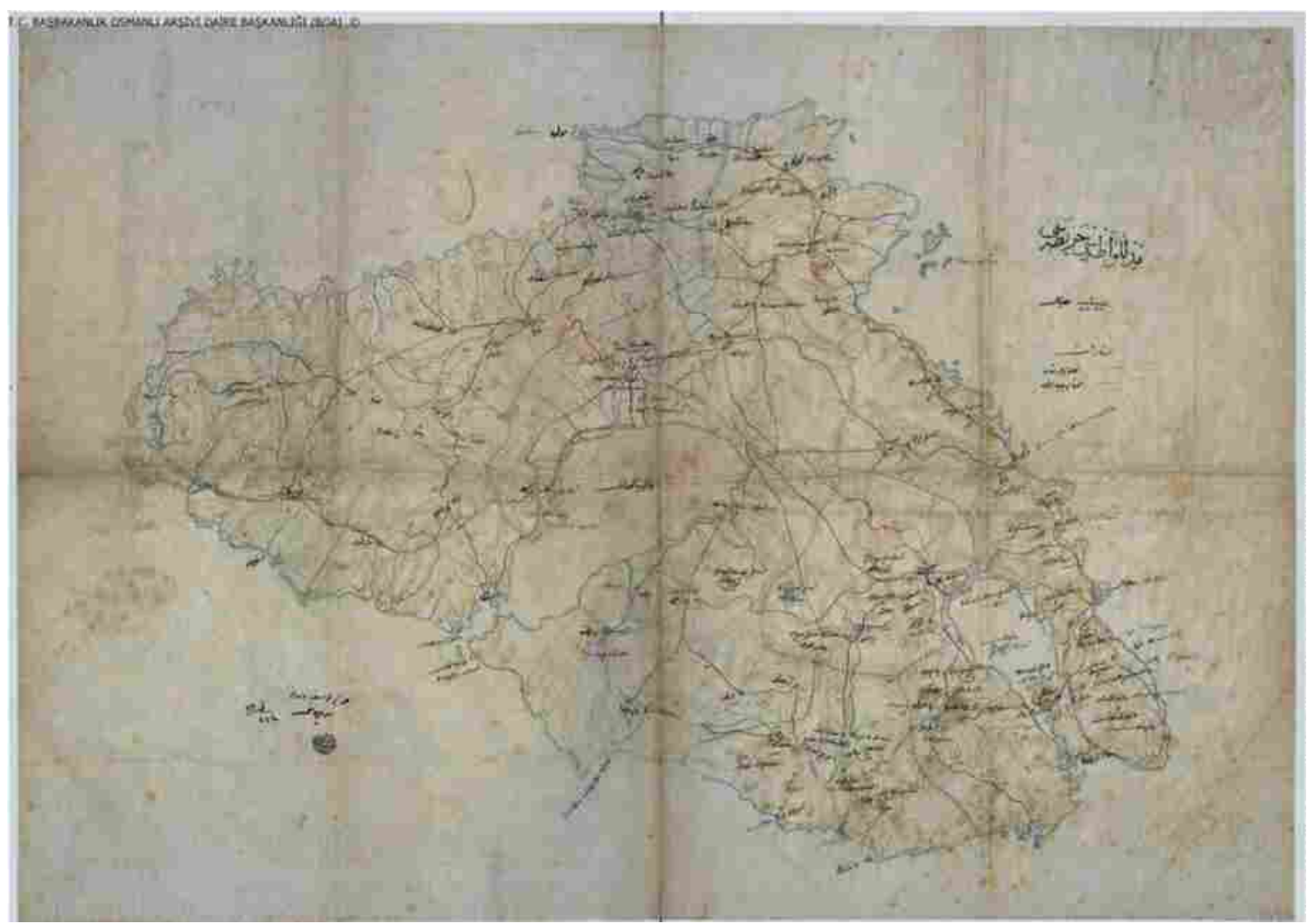

An Ottoman map of Lesvos/Mytilene Island "Cezair-i Bahr-i Sefid” shows Streams, Mountains and Settlements BOA, Haritalar-haritalar (HRT.h..), Gömlek no: 267, H. 28 Ramazan 1313 (M. 13 Mart 1896). Scale 1/100000

\section{LESVOS/MYTILENE UNDER THE OTTOMANS}

The magnitude of the changes is shown in the size of the Byzantine-Genoese successor settlements of the towns of Mytilene and Methymna, which occupy only a fraction of the

\footnotetext{
${ }^{3}$ - For a concise survey of the rich history of the island see: Ernst Kirsten und Wilhelm Kraiker, Griechenlandkunde, ein Führer zu klassischen Stätten, Heidelberg 1962, pp. 531-537. More in: PaulyWissowa, Real-Encyclopädie der klassischen Altertumswissenschaft, XII, pp. 2107-2133, art."“Lesbos.” Also: Siegfried Lauffer (ed.) Griechenland, Lexikon der historischen Stätten, Von den Anfängen bis zur Gegenwart, München 1989, pp. 385-388, 430-433, 451-455 and also 222-223.

${ }^{4}$ - For Molova/Molyvos/Methymna, see in detail: H.G. Buchholz, Methymna, Archäologische Beiträge zur Topographie und Geschichte von Nord-Lesbos, Mainz 1975. A good plan of the town in late-Ottoman period is given by R. Koldewey, Die antiken Baureste der Insel Lesbos, Berlin 1890. A map showing the outlines of the antique city walls of Mytilene on the plan of the modern town is given by Helmut Scharf, Lemnos, Lesbos, Chios, Samos, Ikaria und die Dodekanes, Freiburg in Br. 1988, p. 57.

5 - For the Byzantine period of the island in general, see the rich work of Elisabeth Malamut, Les Iles de l'Empire Byzantine, VIIIe-XIIe Si 'ecles, Paris 1988, (2 vols). For Çaka Bey, see the article of the same name in Türkiye Diyanet Vakfi Islâm Ansiklopedisi, VIII, Istanbul 1993, pp.186-188 by Mücteba İlgürel.
} 
settlements of Antiquity. After a brief occupation by Emir Çaka (1085-'99), the island returned to the Byzantines, who in 1335 gave it to their Genoese allies, the family of Gatteluzzi. ${ }^{6}$ The latter ran the island till 1462, when they were driven out by the Ottomans. The core of the present day castles of Mytilene town and Molova go back to the time of the Gatteluzzi, proof of which is still visible in numerous inscriptions on the walls. After the conquest of Constantinople in 1453, the Ottomans could hardly be expected to tolerate a naval base of one of the strongest Western maritime powers almost immediately at the entrance of the Dardanelles. A pretext was found in 1462 when the petty Gatteluzzi princes, vassals of the sultan, were engaged in exterminating each other. In the spring of that year the Ottoman fleet under Mahmud Pasha and the army under the command of the sultan himself took the town after a short siege. The story is recorded by the Ottoman chroniclers Aşık Paşa-zade, Oruç, Bihişti, Neşri or Kemal Paşa-zade, by sultan Mehmed's Greek eulogiser Kritobulos of the neighbouring island of Imbros, as well as by the Byzantine historians Ducas and Chalkokondylas, among others. Most sources agree that a part of the local majority was left where it was. Most of the castles of the island seem to have been dismantled after the conquest. ${ }^{7}$ Only Mytilene itself and Molova were kept intact and repaired, both receiving an Ottoman garrison; that of Mytilene-town stood in 1521 at 190 men, including 15 gunners. Molova's garrison was smaller, as was its castle. ${ }^{8}$ Immediately after the conquest the island was organised as a separate sandjak divided into two kazas, Midilli and Molova, the first one containing the Southeast of the island, the latter the Northwest. Only in the $19^{\text {th }}$ century was the kaza of Plomari added, grouped around the harbour city of Plomari, which had seen a rapid development since perhaps 1800 .

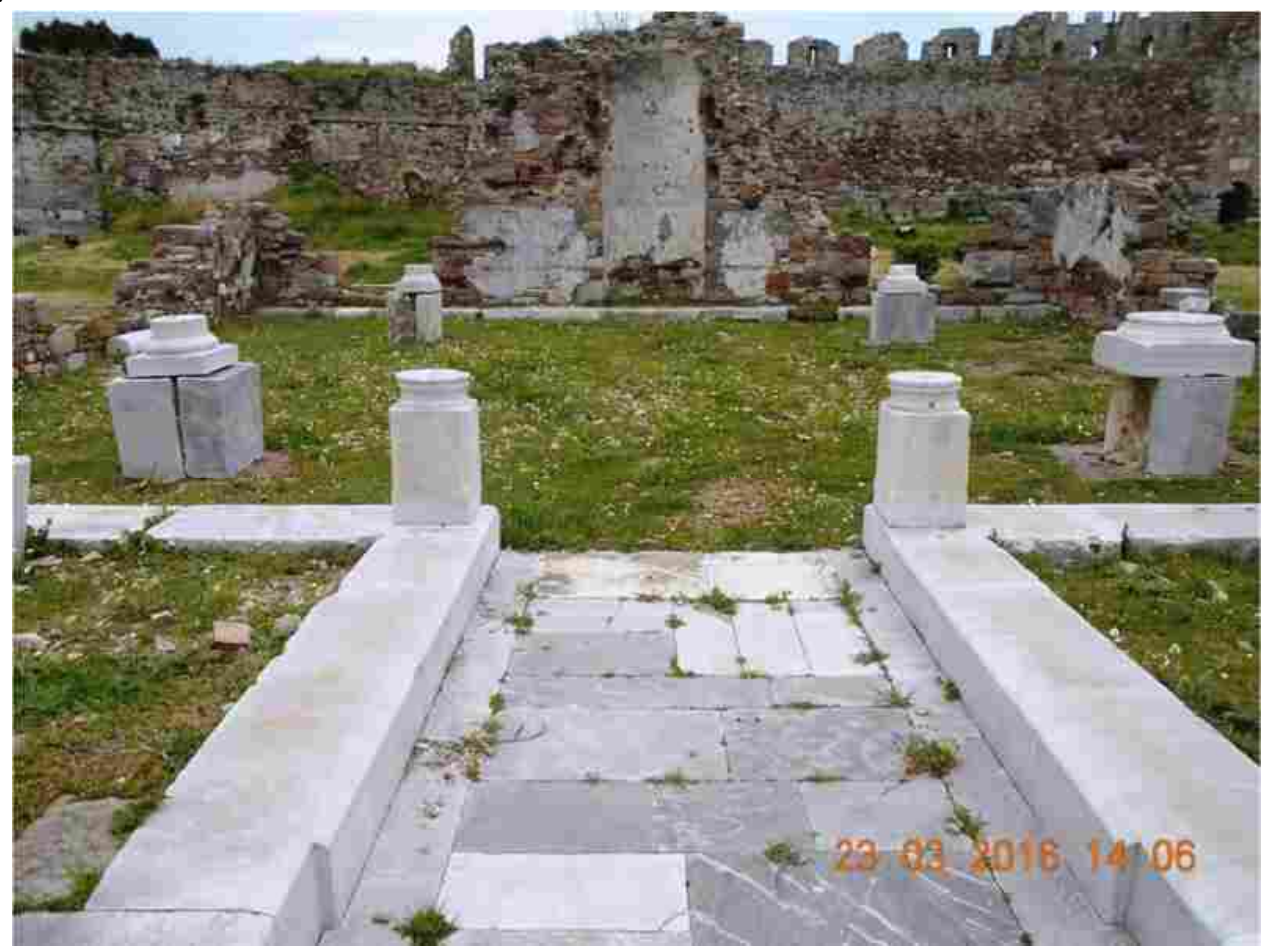

Fig. 1. Midilli "Mytilene” Kale Camii (A. Ameen 2016)

\footnotetext{
6 - For this period, see in detail: William Miller, "The Gattelusj of Lesbos," (1355-1462) in his: Essays on the Latin Orient, Cambridge 1921, pp. 313-353.

7 - First of all the large castles of Eressos and Agioi Theodoroi. For these two and for the other, much smaller castles of the island, see the monograph of Stratis Al. Molinos, Kastra kai Kastrellia, Athens 1984.

8 - Başbakanlık Osmanlı Arşivi, T.D. 367, p. 199.
}

- 165 - $\quad$ The Medrese and Imaret of Hayreddin Barbarossa on the Island of Lesbos/Midilli 
In both towns the conquerors confiscated one church which was transformed into a mosque by adding a minaret, mihrab and minbar. None of these early buildings have survived; Lesbos lies in a zone characterised by heavy earthquakes. Whereas other great Greek islands (Chios, Rhodes, Crete, Paros, Naxos, etc.) still abound with many, often beautiful Byzantine churches, the great and rich island of Lesbos has only two or three left over from this time. What was not destroyed by earthquakes was swept away during the very prosperous $19^{\text {th }}$ century, when the Greek community exerted itself in the erection of numerous large new churches on the sites of the demolished old ones. In the case of Midilli-town, Sultan Mehmed's church-mosque was found in recent decades in the course of the Canadian excavations of Hector Williams. Under the ruins of the mid-19 $9^{\text {th }}$ century Kale Camii (Fig. 1), destroyed after 1912, the foundations of a large three-isled building were found, which was identified as the Roman Catholic cathedral of the Gatteluzzi Lords of the island. At its north-eastern angle, flanking the choir of the old church, the substructure of a large minaret was found. This cannot be anything other than Fatih Sultan Mehmed's mosque, the old basilica, large enough to accommodate the Ottoman garrison and the small Muslim population of the early decades.

There are no numbers for the size of the population of the town of Mytilene from the preOttoman time, nor for the whole island, a feature common to most places in the Eastern Mediterranean. Only the size of the old walled town of Midilli gives us an indication. This old town is situated on a peninsula which is surrounded by the sea on three sides. In Antique and mediaeval times it was cut off from the mainland by a short, narrow canal which connected the South Harbour with the North Harbour of the town. It was the site of the antique Acropolis of Mytilene. In the early Ottoman period the canal was filled in, whereby the castle was directly connected with the rest of the island. The Main Bazar Street of Mytilene town was built upon the old canal. The old walled Byzantino/Genoese town was divided in three parts: the small Inner Castle on the highest spot, accommodating the Palace of the Gatteluzzi Lords, the Upper Castle on the sloping plateau, and the much smaller Lower Castle, all three sections separated from each other by dividing walls. The whole complex covers a space of roughly $200 \times 500 \mathrm{~m}$. applying the usual formula for a medium urban density of 150 inhabitants per hectare we arrive at a population of about 1500 souls. To them should be added a few hundred in the open suburb on the plain grounds on the other side of the old canal, together giving a maximum of 2000 souls. For time and place this was a respectable, medium-sized town. When we take into account that in the $16^{\text {th }}$ century the household number of the town gravitated around 500-600 households we arrive at roughly the same population size.

There is a large body of written sources, all in Ottoman, on the size of the population of the town and the island but this wealth has hitherto barely been touched. The oldest records, the census and taxation survey carried out immediately after the conquest is apparently lost. The first we have is the register of the poll tax of 1491/92. This is followed by the Muhasebe Defter T.D. 367 of 1530, which contains the principal data of the first survey made under Süleyman the Magnificent, thus from 1521/22. Then follow the Mufassal Tahrirs of 1548, 1581, and 1671, all in the Prime Minister's Archive in Istanbul, and finally the Tahrir from 1709, kept in Ankara. In between them is a number of Poll Tax and 'Avariz records, partly preserved in Istanbul (BOA) and partly in the Sofia National Library. Together they allow us to sketch the rough outlines of the demographic history of the island. The series of Ottoman records are closed by the Salnâmes of the late $19^{\text {th }}$ and early $20^{\text {th }}$ century supported by local Greek sources, such as S. Taxis' "Synoptiki Istoria kai 
Topografia tis Lesvou," Cairo 1909. ${ }^{9}$ They give us the following picture:

TABLE I. The population of the Island of Mytilene/Midilli 1488-1900

\begin{tabular}{||c|c|c|c|c|l||}
\hline Year & $\begin{array}{c}\text { Christian } \\
\text { Households }\end{array}$ & $\begin{array}{c}\text { Muslim } \\
\text { Households }\end{array}$ & $\begin{array}{c}\text { Proximate Total } \\
\text { Population }\end{array}$ & $\begin{array}{c}\text { Percentage } \\
\text { Muslims }\end{array}$ & $\begin{array}{l}\text { Source Name/ and } \\
\text { num. }\end{array}$ \\
\hline 1488 & 4952 & $(400)$ & 26200 & $7.47 \%$ & Todorov/Velk. \\
\hline 1491 & 5287 & $(420)$ & 26800 & $7.36 \%$ & Barkan/Ciz. \\
\hline 1521 & 7327 & 659 & 36730 & $8.25 \%$ & T.D. 367 \\
\hline 1548 & 7690 & 807 & & $9.50 \%$ & T.D. 264 \\
\hline 1581 & 8850 & 1331 & 46808 & $13.07 \%$ & T.D. 598 \\
\hline 1602 & 9785 & $(1715)$ & 52900 & $14.91 \%$ & MAD 14773 MA \\
\hline 1644 & 7510 & $(1650)$ & 39400 & $18.01 \%$ & MAD 15249 \\
\hline 1671 & 7500 & $(1660)$ & 32900 & $18.12 \%$ & T.D. 803 \\
\hline 1707 & 7700 & 1680 & 33000 & $17.91 \%$ & Kepeci2606 \\
\hline 1831 & 49270 & 11894 & 61164 Inhab. & $19.45 \%$ & Karal,Nüfus \\
\hline 1900 & 16400 & 3560 & 97800 & $17.84 \%$ & Taxis, Sinop \\
\hline
\end{tabular}

The rapid population growth of the $16^{\text {th }}$ century, the crisis of the $17^{\text {th }}$ century and the even more rapid growth of the later period (1488-1602 a yearly growth of $0.32 \%, 1707-1900,0.56 \%$ ) are clearly visible. A severe break in the $19^{\text {th }}$ century expansion was the terrible epidemic of plague of 1836, when more than 25000 people are said to have died, the "Megálo thanatikó" (Taxis).

Research and composition: M. Kiel '97.

\section{HAYREDDIN BARBAROSSA PASHA \&}

\section{HIS ARCHITECTURAL WORKS IN MYTILENE}

Among the first Turkish settlers of Midilli must have been the father of the famous corsair, adventurer and later Admiral of the Ottoman fleet, Hayreddin Barbarossa. Several contemporary documents, such as the foundation charter of his pious foundations in Istanbul from 1538, call this man Yakub Ağa, who came from the formerly important Ottoman provincial centre Yenice-i Vardar in Macedonia, west of Saloniki. This is recorded by Seyyid Muradi, his biographer, who recorded it out of Hayreddin's mouth. Hayreddin must have been born about 1478. After his adventurous career as ruler of Algiers, and after having been appointed as Ottoman Kapudan Pasha, he not only cared for the creation of a college for higher Islamic learning in Istanbul, next to his still standing türbe in Beşiktaş, but also wished to promote Islamic culture among the few hundred Muslim families of his native Midilli. There, in the middle of the old walled town, a hundred yards down from the Mosque of the Conqueror, he ordered the construction of a monumental building which still stands to this very day, in spite of the destructive forces of

9 - I would like to thank Dr. Martin Strohmeier, Bamberg, for making this rare work accessible to me.

"Barkan/Ciz." = Ömer Barkan, 894 (1488/89) yılı Cizyesinin Tahsilâtına âit Bilançoları, in: Belgeler, Türk Tarih Belgeleri Dergisi, I, 1, Ankara 1964. "Todorov/Velkov" on Table I =' Nikolaj Todorov, Asparuh Velkov, Situation démographique de la Péninsule Balkanique (fin du XVe s. début du XVIe s.), Sofia, 1988 (the Djizye account of 1491). "Karal,Nüfus" = Enver Zia Karal, Osmanlı Imperatorluğunda ilk nüfus sayımı, 1831, Ankara 1943.

- 167 - $\mid$ The Medrese and Imaret of Hayreddin Barbarossa on the Island of Lesbos/Midilli 
nature, and especially of men. The building is visibly a work of the $16^{\text {th }}$ century, of classical Ottoman architecture, although the influence of local workmanship is also evident.
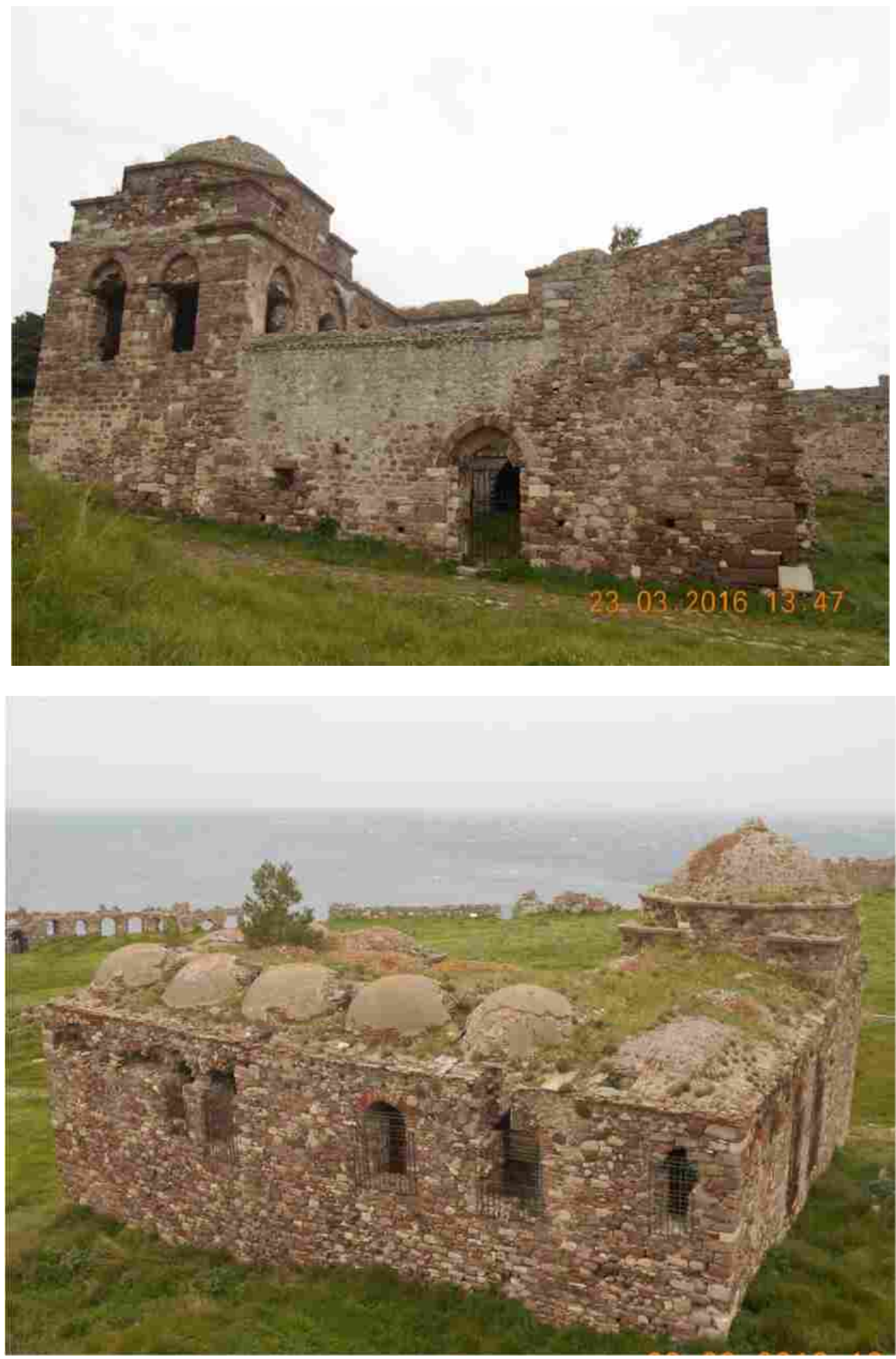

Fig. 2\&3. The Medrese-Imaret-Hankah of Hayreddin Barbarossa Pasha in Midilli "Mytilene" (A. Ameen 2016) 
Written sources on the building seem to be scant. The Midilli foundations of Hayreddin are apparently not mentioned in the preserved Vakfiye, which only deals with his Istanbul buildings (medrese, mescid, mekteb, türbe in Beşiktaş and a hamam in the Zeyrek Mahalle in old Istanbul). The biographer of scholars, Nev'i-zâde 'Ata'i is apparently the only Ottoman source to mention that Hayreddin made a medrese in Midilli. ${ }^{10}$ Other sources, however, suggest that it was a hankah (Khanqah), whereas we found a survey of the expenditure of the building from the year 1550 where the building is definitely called an "Imaret" (Topkap1 Sarayı Müzesi, Archives, D. 1889). Perhaps it was all three at once. The building itself gives at least part of the answer. As to its date of construction there need not be any doubt. Hayreddin came back from Northern Africa and became Kapudan in December 1533, and he died in July 1546. Moreover, the biographies of the $16^{\text {th }}$ century Ottoman Medrese professors as collected by Cahid Baltac1 from contemporary biographies mention that Pir Ahmed of Karaman, better known as Piri Reis, was appointed as the first Müderris of the Medrese of Hayreddin Pasha before he was appointed professor of the Beşiktaş medrese. ${ }^{11}$ Before his appointment in Midilli he had been the teacher of Hayreddin Pasha. According to 'Ata'i, Pir Ahmed ended his career with the lofty post of Kadı of Istanbul, where he died in 973 (1565/66) and was buried in Eyyüb. Pir Ahmed's appointment at the Beşiktaş medrese in 1546 so that the date of construction of the Midilli medrese can be narrowed down to 13 years only; a date for the construction of the medresse in the late 1530's seems the most likely. As no foundation inscription is preserved at the building and the Vakıfnâme has not shown up yet we have to content ourselves with these dates. ${ }^{12}$

Disregarding the Ottoman additions to the castles of Midilli and Molova, which we reserve for a separate study, the foundation of Hayreddin Pasha is the most important Ottoman construction still standing on the island. It presents itself as a two-storied building around a cloistered courtyard, dominated by a tall, domed classroom on one of the corners. The building occupies a rectangle, $21.70 \times 19.00$ meters with the greatest length along the narrow main street of the old town. The entrance gate and the classroom are also on the main street. A little to the south of it stands a massive $19^{\text {th }}$ century Ottoman powder magazine "Baruthane" now restored by the Greek Archeological Service and serving as their depot. Still further south, towards the main town gate, are the ruins of the Kale Camii mentioned previously (Fig. 1). Opposite the building of Hayreddin Pasha are the extensive ruins of what must have once been the barracks of the Ottoman garrison. They are built in the style of the late $19^{\text {th }}$ century. A few meters further down opposite the road is a small, rather low, single-domed structure built in the same style and technique as the main building of Hayreddin. It can hardly have been anything other than a mekteb (Primary School) belonging to the same foundation.

The main building shows the plan of an incomplete letter U. One enters the building through an eccentrically placed entrance in the front wall. To the right is a very ruined section with a long barrel-vaulted corridor which opens into two rooms, one vaulted and

\footnotetext{
10 - Nev’i-zâde, Atâi, Hadîkatü'l-Hadayik, Istanbul 1268 , p. 55.

11 - Cahid Baltacı, XV-XVI. Astrlarda Osmanlı Medreseleri, Istanbul 1976, p. 100 and 297.

12 - For the Vakfiye of Hayreddin Pasha for his Istanbul foundations, see: İ. Hakkı Konyalı, "Hayreddin Paşa Vakfiyesi," in: Yeni Sabah Gazetesi, 24 Ağustos 1943. The original is in Vakıflar Genel Müdürlügüu, No 571, Istanbul Sân̂ Defteri, pp. 184-190. We were unable to see this important document. For a modern Turkish translation of it, see: Emin Yakıtal, "Büyük Amiral Hayrettin Barbaros'un Vakfiyenamesi," in: Deniz Mecmuast, LVII, 375, Istanbul 1945, pp. 43-51. I would like to thank Prof. Kutgün Eyüpgiller of İTÜ for making this article available to me. It deals only with the Vakf of Hayreddin Pasha in Istanbul and not with Midilli.
}

- 169 - The Medrese and Imaret of Hayreddin Barbarossa on the Island of Lesbos/Midilli 
the other covered with a wooden ceiling. Immediately to the left of the entrance, a flight of stairs lead up to the large, tall, domed room on the second floor of the building, and further, to the U-shaped arcade. The main room measures $5 \times 5 \mathrm{~m}$ inside and is covered by a dome sitting on four pendentives. The walls of the room and all other parts are covered on the inside with plaster, or at least have been so. The way that the inner space of the main room is treated, its form and proportions, are typically 16th century classical Ottoman. The remaining part of the left wing of the building is occupied by three cross-vaulted cells, all equipped with cupboards in the walls and a fire place. The rear wall of the building has five, similar rooms, all domed, and each one fitted out with a fireplace and cupboards. The room in the corner is also the third room of the left lateral wing. On the right lateral side there are only three rooms, making a total of ten rooms of which nine are domed (Figs. 34). Without doubt, the upper part of the building is the medrese of Hayreddin Pasha as mentioned in the $16^{\text {th }}$ century sources. With a spacious dershane and separate rooms for the students, its plan shows nothing unusual, apart from the high blind wall which separates the courtyard from the street. In front of the student cells and the ground floor section runs a two story arched portico, the Ottoman four-centered arches resting on square masonry pillars.

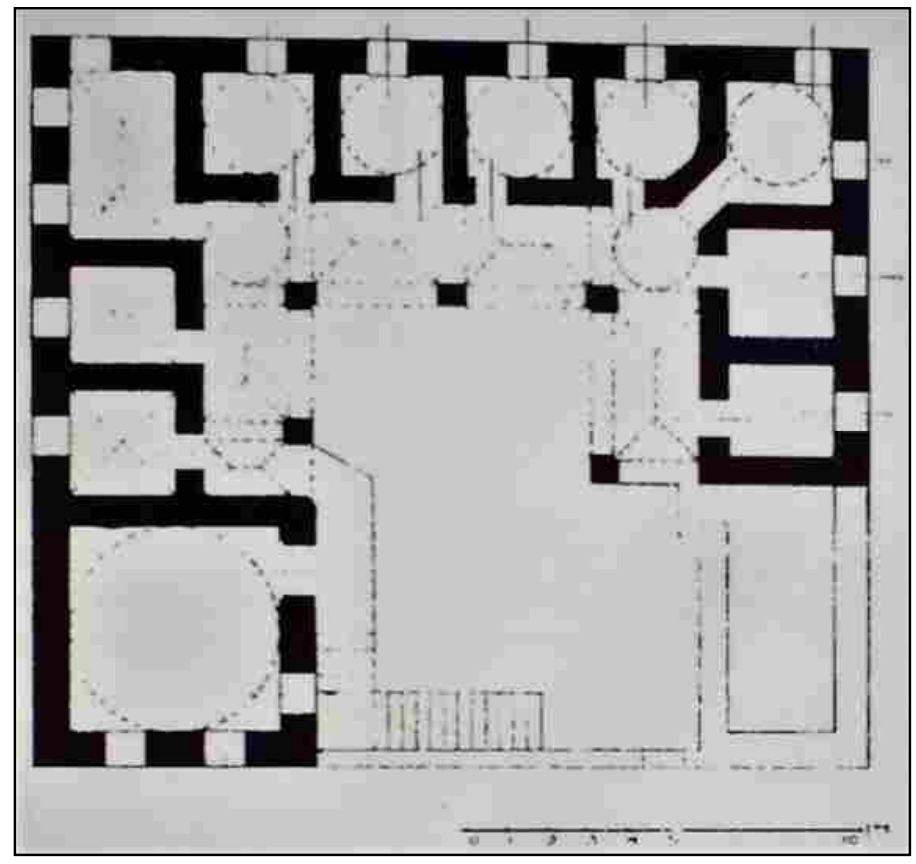

Fig. 4. The Medrese-Imaret-Hankah of Hayreddin Pasha in Mytilene, a plan of the $1^{\text {st }}$ floor (Orlandos, "O medreses tou Kastrou tis Mytilenes," p. 122, Pl. 1)

The ground floor of the building definitely had a different function. The space underneath the classroom has a massive, square central pillar supporting two barrel-vaults. The adjacent room along the left wall is also equipped with an inner pillar. This pillar supports one barrel-vault and two much smaller flat cross-vaults. Moreover this second room has some large fireplaces, big enough to be used as a kitchen to cook large quantities of food. We can be sure that the room beneath the dershane of the medrese was the refectory of the institution. It is big enough to accommodate twenty people at once, and well lit by two windows in the outer wall. The remaining part of the left wing of the ground floor, the third 
part, is occupied with one large, dark, rectangular barrel-vaulted room with only one window placed high up in the walls, and no fireplaces or cupboards. It can hardly be anything other than a storeroom/kilar. The three rooms together must have formed the Imaret as mentioned in the sources.

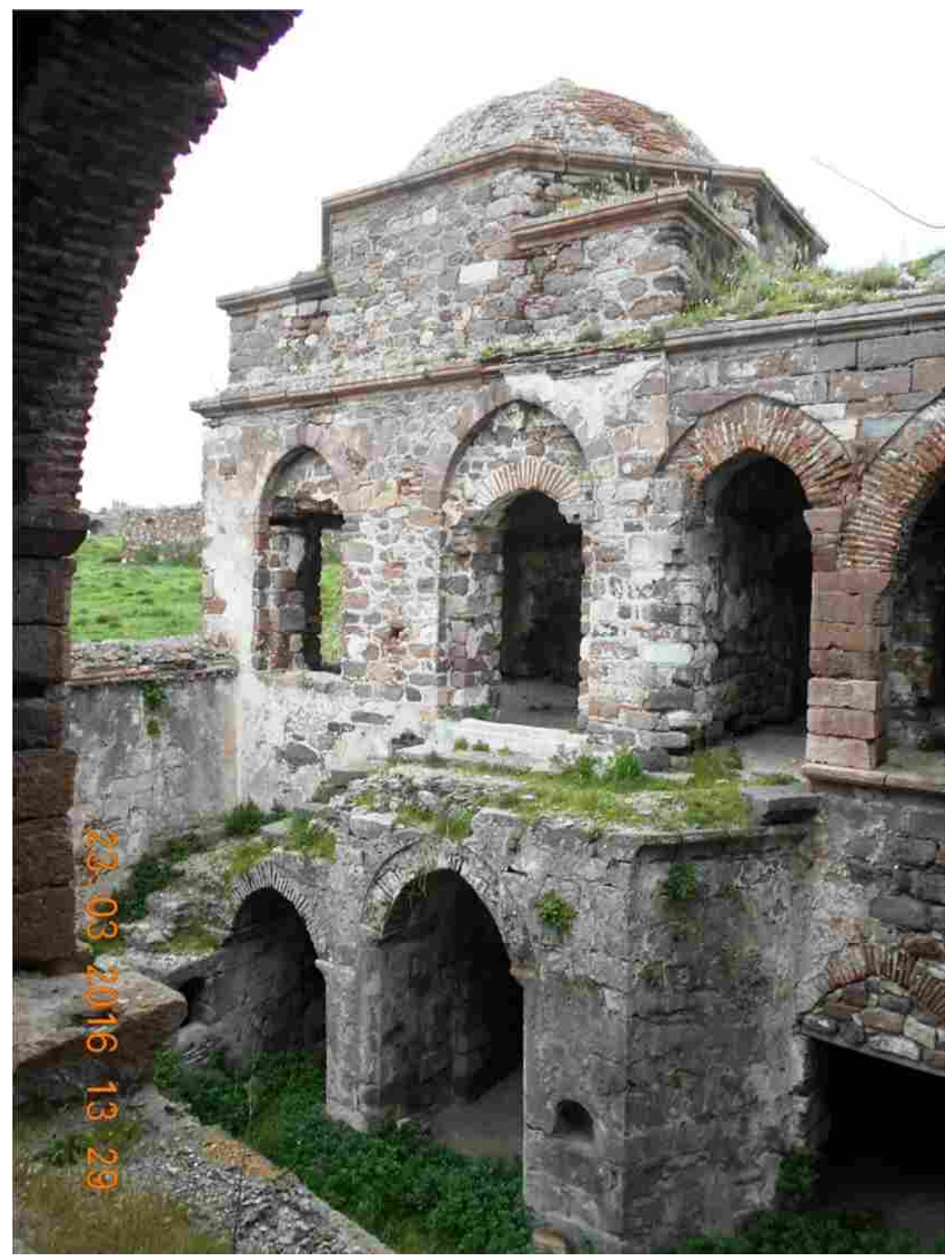

Fig. 5. The Medrese-Imaret-Hankah of Hayreddin Pasha "Mytilene", the dershane \& the rooms beneath it (A. Ameen 2016)

It is more difficult to determine the function of the remaining rooms on the ground floor. Three of them, flanking the storeroom along the rear wall of the building, are domed, and

- 171 - $\quad$ The Medrese and Imaret of Hayreddin Barbarossa on the Island of Lesbos/Midilli 
have (or originally had) cupboards and fireplaces. They may have been additional student cells. The remaining rooms are rectangular, 2.60 meters wide and about six meters long. They have no fireplaces and are covered with barrel-vaults, not with domes. It could be suggested that they were the rooms for members of one or another Orthodox dervish order, most probably the Halvetiye, which were rapidly expanding in the early $16^{\text {th }}$ century, and were a much sought-after instrument in the hands of the government to spread Islam in alien areas. ${ }^{13}$ Living an ascetic life they could do without fireplaces. The now ruined rooms in the corner to the right of the entrance must also have had a function related to dervish practices (sema'hâne ?); yet their present condition is too ruined to allow definite conclusions. As a whole, the way the building is set up argues for a multiple function of medrese, imaret (in the sense of soup-kitchen) and a hankah, as is clearly pointed at in the source we are going to publish here, where five "Sufilar" appear, together with a "Şeyh-i Kebîr and a person called Mesih Baba. The Vakıfname of the foundation will have the last word here. ${ }^{14}$

When working at the Topkapı Sarayı Arşivi we have been so fortunate to find a survey of the expenditure of the Imaret of Hayreddin Pasha of the year 1550 as mentioned above. It is T.S.M.A., D. No 1889, two large pages of text and a shorter note on the third page, giving us a detailed insight into how this institution functioned, and what was spent on food and salaries. The heading of the document reads as follows:

"This register describes the expenditure of the Imaret of the late Hayreddin Pasha on the island of Midilli from the beginning of the month Muharrem of the year 957 onward." (20 January 1550).

Then follows a survey, kept month by month of the quantity and price of foodstuffs, given one by one: nân, guşt, pirinç, kendüm, 'asel, revgan-i zeyt, nemek ma' piyaz, as well as a total of the monthly salaries. We give the contents of this survey in the form of a table to avoid endless repetition of the same words. The quantities of rice and wheat for the soup is given in keyl, that of honey and olive oil in okka (vuqiye). The quantities of wheat for bread, and meat are not given, only their prices appear. It is visible that in eleven of the twelve months the quantities of foodstuffs bought remained the same. The differences there are caused by the number of days the lunar month has: six months of 30 days, four of 29 days and two (Şevvâl and Zû'l-hicce) only 27 days. Only during the month of Ramazan (Ramadan) much more was spent on food (especially on honey and olive oil), to celebrate the holy nights of the month of fast.

It can be seen in the 1550 list that the price of one keyl of rice was 11 Akçe. Wheat was 12 Akçe per keyl. If the keyl of Istanbul was used here, $(25,656 \mathrm{~kg})$, which is unlikely, we would arrive at $64 \mathrm{~kg}$ of wheat per day for bread, $17 \mathrm{~kg}$ for the soup, and $26 \mathrm{~kg}$ of rice per day. In 1540, according to the Tahrir Defter of the Livâ of Eğriboz, the keyl of Eğriboz and

\footnotetext{
13 - See, in detail, the rich monography of Nathalie Clayer, Mystique, 'Etat et Société. Les Halvetis dans l'air balkanique de la fin du XVe si ecle 'a nos jours, Leiden-New York 1994, p. 424.

14 - This, and many other details of the cultural history of the island of Midilli under the Ottomans, could be found in the 16-18 volumes of Kadı Sicills of Midilli, preserved in the Archive of Vakıflar Genel Müdürlüğü in Istanbul-Sirkeci, which unfortunately is closed for research. A nice task for the future. For the Ottoman medrese as a building see i.a.: Ernst Egli, Sinan, Der Baumeister osmanischer Glanzzeit, Zürich/Stuttgart 1976., pp. 114-1166; Godfrey Goodwin, A History of Ottoman Architecture, London 1971, passim; and especially the rich works of Zeynep Ahunbay, "Mimar Sinan "nin Eğitim Yapıları," in: Mimarbaşı Koca Sinan yaşadığ çă̆ ve Eserleri, İstanbul 1988, pp. 239-309, and the article "Medreseler" in: Dünden Bugüne İstanbul Ansiklopedisi, vol 5, Ist. 1994, pp. 320-326.
} 
Athens was eight keyl of Istanbul, or $208 \mathrm{~kg}$. Its fixed price was, according to the same source, 50 Akçe. Both Eğriboz and Attica, the land around Athens, were, like Midilli, not very suitable for wheat growing. Thus their prices might have been roughly comparable. If this is so, the yet unknown keyl of Midilli must have been about four times less than that of Eğriboz and Attica, or about fifty $\mathrm{kg}$. If we accept this rough calculation, the $75 \mathrm{keyl}$ of wheat per month represent $125 \mathrm{~kg}$ of wheat per day for bread, $(75 \times 50: 30), 33 \mathrm{~kg}$ of wheat for soup, and $50 \mathrm{~kg}$ of rice. Cooks usually reckon 100 gram of rice per person, per meal. When the Midilli Imaret distributed food twice a day, as was usual in these institutions, 250 persons could be fed daily. The staff of the building, including the dervishes, and the 12 students, totalled 26 persons. A large amount of food, therefore, could be spent on the poor, and on travellers. We leave it up to the reader to decide which measure would have been used. Even if the smaller unit of measurement is taken the amount of food prepared and distributed in this benevolent institution was considerable.

\section{TABLE II. Prices and Quantities of Foodstuffs for the Midilli İmaret in 1550} T.K.S.M., D. 1889

\begin{tabular}{|c|c|c|c|c|c|c|c|c|c|c|c|c|}
\hline & Muh. & Safar & Rebi I & $\begin{array}{c}\text { Rebi } \\
\text { II }\end{array}$ & Cem. I & $\begin{array}{c}\text { Cem. } \\
\text { II }\end{array}$ & Receb & Şaban | & Ram.|| & Şev. & $\begin{array}{c}\text { Zi'l- }^{\prime} \\
\text { H. }\end{array}$ & $\begin{array}{l}\text { Zi'l- } \\
\text { Kade }\end{array}$ \\
\hline Bread/Akçe & 900 & 870 & 900 & 870 & 900 & 870 & 900 & 870 & 900 & 810 & 900 & 810 \\
\hline Meat & 750 & 725 & 750 & 725 & 750 & 725 & 750 & 725 & 750 & 675 & 750 & 675 \\
\hline Rice/Keyl & 30 & 30 & 30 & 30 & 30 & 30 & 30 & 30 & 75 & 38 & 30 & 30 \\
\hline Rice/Akçe & 330 & 330 & 450 & 450 & 450 & 450 & 450 & 450 & 1125 & 450 & 450 & 360 \\
\hline Wheat/Keyl & 20 & 20 & 20 & 20 & 20 & 20 & 20 & 20 & 1 & 18 & 20 & 18 \\
\hline Wheat/Akçe & 240 & 240 & 240 & 240 & 210 & 210 & 100 & 200 & 1 & 175 & 200 & 180 \\
\hline Honey/Okka & 20 & 20 & 20 & 20 & 20 & 20 & 20 & 20 & 150 & 20 & 20 & 20 \\
\hline Honey/Akçe & 72 & 72 & 72 & 72 & 72 & 72 & 72 & 72 & 541 & 72 & 72 & 72 \\
\hline \begin{tabular}{|l} 
Olive Oil/ \\
Okka
\end{tabular} & 18 & 18 & 18 & 18 & 18 & 18 & 18 & 18 & 135 & 18 & 18 & 18 \\
\hline Olive Oil/Akçe & 144 & 144 & 108 & 108 & 108 & 108 & 108 & 108 & 810 & 108 & 108 & 162 \\
\hline $\begin{array}{l}\text { Salt a. } \\
\text { Onions/Akce }\end{array}$ & 45 & 45 & 45 & 45 & 45 & 45 & 45 & 45 & 45 & 45 & 45 & 45 \\
\hline $\begin{array}{l}\text { Firewood/ } \\
\text { Akçe }\end{array}$ & 110 & 110 & 110 & 110 & 110 & 110 & 110 & 110 & 110 & 110 & 110 & 110 \\
\hline Total Cost & 2591 & 2536 & 2675 & 2620 & 2645 & 2590 & 2635 & 2580 & 4281 & 2390 & 2335 & 2414 \\
\hline Total Salaries & 1200 & 1200 & 1200 & 1200 & 1200 & 1200 & 1200 & 1200 & 1200 & 1200 & 1200 & 1200 \\
\hline
\end{tabular}

Extra Expenditure for Guests: honey, 24 Okka, 330 Akçe; Rice $9.5 \mathrm{Keyl}$, 130Akçe; Olive Oil 26 Okka, 156 Akçe. Total for the guests: 621 Akçe.

Extra Expenditure for the Imaret: 586. Total Expenditure: 32,591.

Total Salaries: 14,400 .

General Total: 46,991.

Initial available money (așl mal) 48,198. Left over 1,207.

(Research and composition: M. Kiel '97.)

- 173 - $\mid$ The Medrese and Imaret of Hayreddin Barbarossa on the Island of Lesbos/Midilli 
On the third and last written page of our document is a survey of the staff of the Imaret and their daily payment as well as provisions for a few dervishes, evidently also living in the building. The text reads as follows:

"Register describing the daily payment of the servants of the Imaret
of Midilli. Year 957 (1550). Grand Sheikh, per day 7 (Akçe). Katip
Sinan, per day 3, Sheikh of the Imaret, per day 3, Daily payment for
the Sufis, 5, Cook, per day 3, second Cook, per day 3, Steward (Nakib)
per day 2, Gate Keeper, per day 2, Honey Collector, per day 2,
Noktacl, per day 3, Cellar Master, per day 2, Rice Cleaner, per day 2,
Mesih Baba, per day 2, Repairer, per day 1.
Per Day: 40 (Akçe); Per Month: 1200."

Thus a yearly total of 14,400 akçe was reserved for salaries for the staff and for the dervishes. In the kitchen alone 11 persons were appointed. Besides them there were two dervish leaders and very probably five common dervishes. The Medrese must have been run by a separate group of people. It is not, however, mentioned in our document, which only pertains to the Imaret/Hankah. As the medrese was classified as an "Otuzlu" ("Thirtier"); another 10,650 Akçe was spent on the salary of the professor, perhaps 2000 for his assistant and 4260 per year for pocket money for the 12 students living in the medrese cells. Thus altogether there was a further expenditure of almost 17000 Akçe per year for the medrese alone. Including the expenditure for food and salaries for the Imaret and the Hankah, the total yearly expenditure for the whole building was about 64,000 Akçe per year; for its time and place, a considerable sum. The money for the upkeep of the foundation must have come from outside the island, because in none of the three tahrirs of Midilli, made after the completion of the building in question (from 1581, 1671 and 1709), can a word about Hayreddin's Vakf on the island be found. Here more research in the Ottoman archives is required, research which would shed more light on the cultural history of the island in general, and on the remarkable building of Hayreddin in particular.

\section{OTTOMAN ARCHITECTURE HERITAGE IN MYTILENE}

Hayreddin Barbarossa's Medrese-Imaret-Hankah is not the only Ottoman monument still standing on the island of Midilli. In 1501, 1572, and 1644 important modernisation works were carried out on the two castles of the island, each marking a major military crisis, and each stage documented by Ottoman inscriptions. The town of Midilli still has four mosques standing, dating from the late- $18^{\text {th }}$ to the early $20^{\text {th }}$ century.

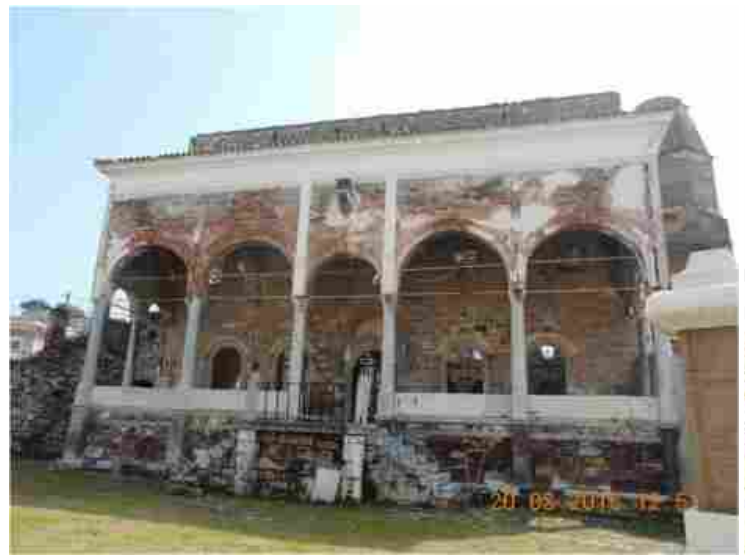

Fig. 6. The Yeni Mosque "Mytilene", (A. Ameen 2016)

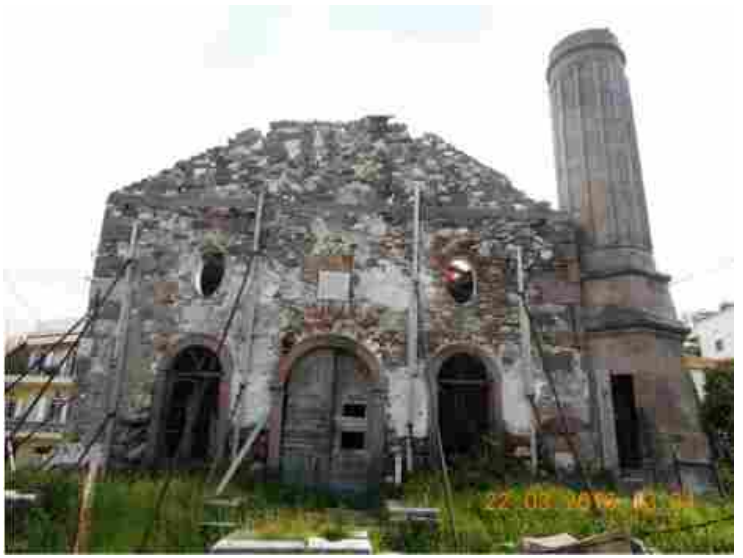

Fig. 7. The Valide Mosque "Mytilene", (A. Ameen 2016) 
Two Hamams also stand. Elsewhere on the island almost a dozen village mosques (among them the highly elegant Baroque mosque of Mesagros from 1821), and a similar number of Hamams and Ilica's still stand. We have collected all the documentation about them and are currently working on its publication. The fact that such a remarkable building as that of the most famous Admiral of the Ottoman fleet could escape scholarly attention may serve as an illustration of how much still need to be done to reconstruct the cultural history of the former European provinces of the Ottoman Empire. ${ }^{15}$
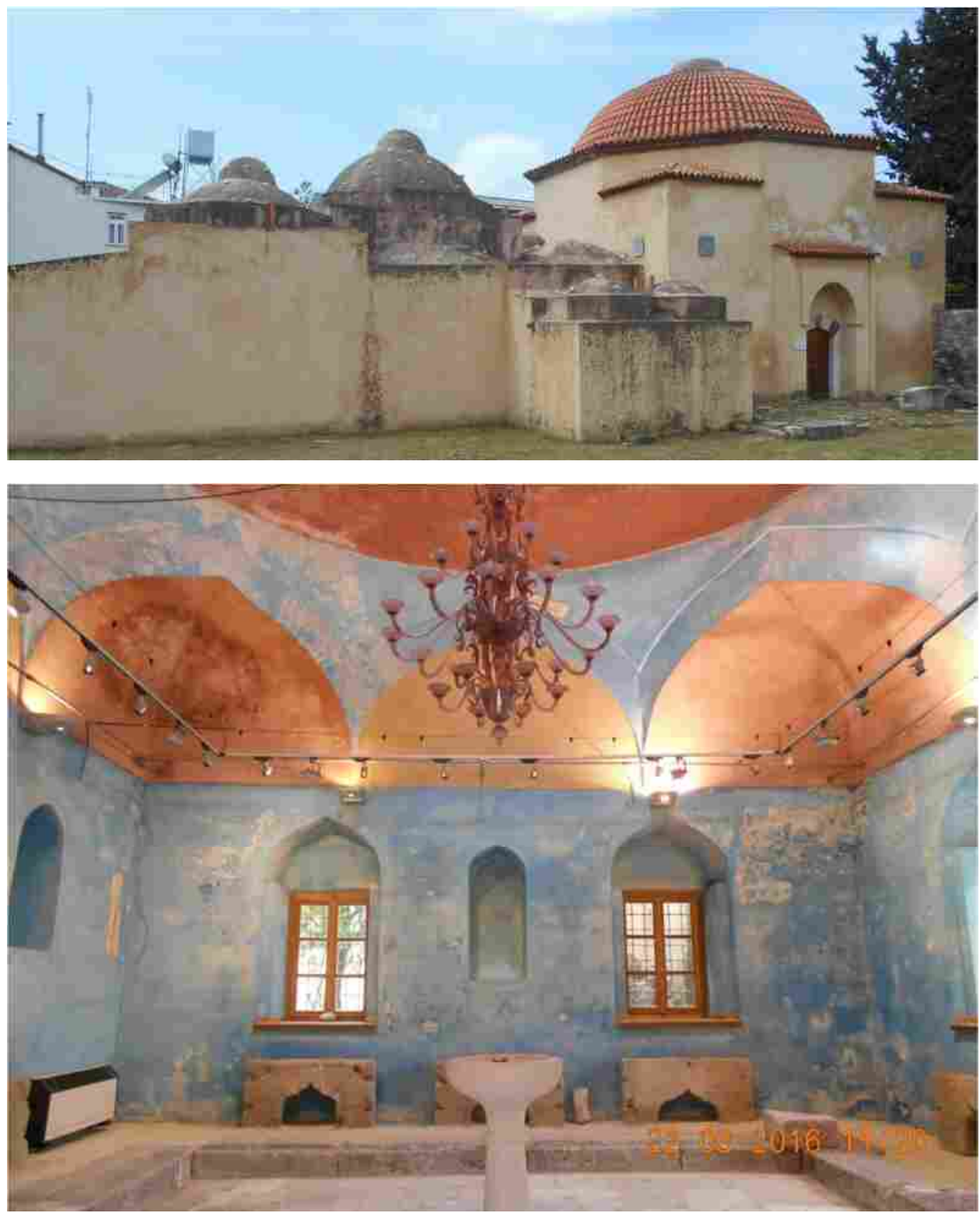

Fig. 8\&9. Çarşı Hammamı "Mytilene”, (A. Ameen 2016)

\begin{abstract}
15 - An exception is the little pioneer study of the indefatigible Anastasis K. Orlandos, "O medreses tou Kastrou tis Mytilenes," in: Imerólogion tis Megális Elládos, Athens, 1921, pp. 121-128, which I could use thanks to the courtesy of Prof. Dimitris Karidis, Athens. It does not, however, contain the date of construction of the building nor any remark on the identity of its important founder. The otherwise comprehensive Ekrem Hakkı Ayverdi, Avrupa'da Osmanlı Mimari Eserleri, IV, Bulgaristan, Yunanistan, Arnavutluk, Istanbul 1982, leaves Midilli-Mytilene out completely.
\end{abstract}

- 175 - $\mid$ The Medrese and Imaret of Hayreddin Barbarossa on the Island of Lesbos/Midilli 


\section{REFERENCES}

"Barkan/Ciz." = Ömer Barkan, 894 (1488/89) yılı Cizyesinin Tahsilâtına âit Bilançoları, in: Belgeler, Türk Tarih Belgeleri Dergisi, I, 1, Ankara 1964.

"Karal,Nüfus" = Enver Zia Karal, Osmanlı Imperatorluğunda ilk nüfus sayımı, 1831, Ankara 1943.

"Todorov/Velkov" on Table I $=$ ' Nikolaj Todorov, Asparuh Velkov, Situation démographique de la Péninsule Balkanique (fin du XVe s. début du XVIe s.), Sofia, 1988 (the Djizye account of 1491).

Albülbaki Gölpınarlı, Mevlanâ'dan sonra Mevlevilik, Istanbul 1953 (and further editions).

Başbakanlık Osmanlı Arşivi, T.D. 367, p. 199.

Cahid Baltac1, XV-XVI. Astrlarda Osmanlı Medreseleri, Istanbul 1976.

E.H. Ayverdi, Avrupa'da Osmanli Mimari Eserleri IV: Bulgaristan, Yunanistan, Arnavutluk. Istanbul: Istanbul Fetih Cemiyeti, 1982.

Elisabeth Malamut, Les Iles de l'Empire Byzantine, VIIIe-XIIe Si 'ecles, Paris 1988, (2 vols). Emin Yakıtal, "Büyük Amiral Hayrettin Barbaros'un Vakfiyenamesi," in: Deniz Mecmuasl, LVII, 375, Istanbul 1945, pp. 43-51.

Ernst Egli, Sinan, Der Baumeister osmanischer Glanzzeit, Zürich/Stuttgart 1976.

Ernst Kirsten und Wilhelm Kraiker, Griechenlandkunde, ein Führer zu klassischen Stätten, Heidelberg 1962.

Godfrey Goodwin, A History of Ottoman Architecture, London 1971.

H.G. Buchholz, Methymna, Archäologische Beiträge zur Topographie und Geschichte von Nord-Lesbos, Mainz 1975.

Helmut Scharf, Lemnos, Lesbos, Chios, Samos, Ikaria und die Dodekanes, Freiburg in Br. 1988.

İ. Hakkı Konyalı, "Hayreddin Paşa Vakfiyesi," in: Yeni Sabah Gazetesi, 24 Ağustos 1943.

K. Orlandos, "O medreses tou Kastrou tis Mytilenes," in: Imerólogion tis Megális Elládos, Athens, 1921, pp. 121-128,

Kadı Sicills of Midilli, 16-18 volumes, Archive of Vakıflar Genel Müdürlüğ̈̈ in IstanbulSirkeci.

M. Kiel, "Quellen zur Geschichte des Mevlevi-hâne von Midilli/Lesbos" in print

Mücteba İlgürel, "Çaka Bey," Türkiye Diyanet Vakfi Islâm Ansiklopedisi, VIII, Istanbul 1993, pp.186-188.

Nathalie Clayer, Mystique, 'Etat et Société. Les Halvetis dans l'air balkanique de la fin du

XVe si 'ecle 'a nos jours, Leiden-New York 1994.

Nev'i-zâde, Atâi, Hadîkatü'l-Hadayik, Istanbul 1268.

Pauly-Wissowa, "Lesbos," Real-Encyclopädie der klassischen Altertumswissenschaft, XII, pp. 2107-2133.

R. Koldewey, Die antiken Baureste der Insel Lesbos, Berlin 1890.

Sakıb Mustafa Dede, Sefine-i nefise-i Mevleviyân, Cairo 1283 (1866/67).

Siegfried Lauffer (ed.) Griechenland, Lexikon der historischen Stätten, Von den Anfängen bis zur Gegenwart, München 1989.

Stratis Al. Molinos, Kastra kai Kastrellia, Athens 1984.

Vakıflar Genel Müdürlüğü, No 571, Istanbul Sânî Defteri, pp. 184-190.

William Miller, "The Gattelusj of Lesbos (1355-1462)," in his: Essays on the Latin Orient, Cambridge 1921, pp. 313-353.

Zeynep Ahunbay, "Medreseler" in: Dünden Bugüne Istanbul Ansiklopedisi, vol 5, Ist. 1994, pp. 320-326.

Zeynep Ahunbay, "Mimar Sinan "nin Eğitim Yapıları,” in: Mimarbaşı Koca Sinan yaşadı̆̆ çăg ve Eserleri, İstanbul 1988, pp. 239-309.

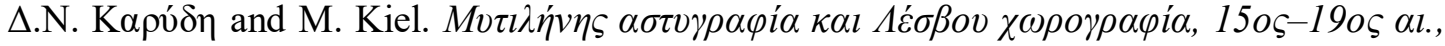

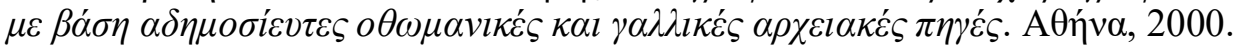

